\title{
Livelihood trends in Response to Climate Change in Forest Fringe Communities of the Offin Basin in Ghana
}

\author{
**AMISAH ${ }^{1}$, S.; GYAMPOH ${ }^{1}$, A. B.; SARFO-MENSAH ${ }^{2}$, P.; QUAGRAINIE ${ }^{3}$, K. K. \\ ${ }^{1}$ Faculty of Renewable Natural Resources, Kwame Nkrumah University of Science and Technology, Kumasi, Ghana. ${ }^{2}$ Bureau of Integrated \\ Rural Development, Kwame Nkrumah University of Science and Technology, Kumasi, Ghana. ${ }^{3}$ Purdue University, Department of \\ Agricultural Economics, West Lafayette, Indiana, USA.
}

\begin{abstract}
The livelihoods of forest fringe communities in Ghana depend, largely, on the renewable natural resources that they can find in the forests and any activities that impacts on the integrity of the forest disrupt the livelihood of the dependent communities. Forest fragmentation continues to take place in Ghana, mainly in response to a growing demand to feed an ever increasing population and for timber exploitation for export. One of the forest fringe communities in Ghana where the rural livelihoods of the people have been compromised due to deforestation and climate change is the Offin basin. The removal of forests impacts on local climate, water availability, and livelihoods due to influence of forests on precipitation and water balance. Fluxes in the quantity and frequency of rainfall contribute to decreasing food production and water availability. This study examines forest loss, precipitation and ambient temperature patterns in the forest fringe communities in the Offin river basin over the past four and a half decades and assesses current impacts and trends on rural livelihoods and coping strategies by the communities. The forests provide the communities with fuel-wood, fish and game, medicinal plants, food sources, and recreation. Between 2000 and 2005 deforestation rate in the basin was 2\%. Mean annual precipitation decreased by $22.2 \%$ between 1960 and 2000 in response to a $1.3^{\circ} \mathrm{C}$ rise in ambient temperature over the same period. Considerable changes in the frequency of rainfall and its unpredictability impacted negatively on the livelihood of the fringe communities who are predominantly cocoa and subsistence crop farmers. The livelihood resources of the community are severely constrained leading to reduction in food security and economic losses. In response to deforestation and associated climatic changes, several coping strategies for sustenance of livelihoods have been adopted by the forest fringe communities. @ JASEM
\end{abstract}

Forest fragmentation and deforestation remains a central problem in the high forest zone of Ghana due, primarily, to both legal and illegal timber exploitation and arable crop farming. The consequence has been a dramatic change in climate and evolution of strategies to sustain rural livelihoods. In most African countries deforestation rates have increased over the past four decades, with significant effects on rainfall, temperature, water resources, wildfire frequency, agriculture and livelihoods. At the beginning of the century, a third of Ghana's land area of 238,533 km² was covered by high forest whilst the remaining was savannah woodland. Currently, only about $10 \%$ of this area remains as forested land and logging, bush fires, agricultural practices, excessive exploitation of Non Timber Forest Products (NTFPs) have been implicated. Deforestation rates remain high and will probably increase in the coming years as the population grows and demand for new settlements, wood for construction, fuelwood, charcoal and food increases as a consequence. The resultant effects on the local climate is decreasing rainfall, increase in droughts, floods and other extreme weather events adding to stress on water resources, food security, health, infrastructure and thus overall development.

Ghana has experienced a significant decline in rainfall levels since the early 1960s (Nicholson 1994; Hulme, 1994). The decline is large enough to suggest a significant change in the normal regional climate (Eltahir 1992; Farmer and Wigley 1985). A

\footnotetext{
* Corresponding author: Amisah, S.
}

little break in decline in rainfall was observed in 1994, the wettest in West Africa since 1960 (Nicholson et. al., 1996), after which the decline continued further (Horton and Parker, 1997).

Ghana has a humid tropical climate with an annual mean temperature between $26^{\circ} \mathrm{C}$ and $29^{\circ} \mathrm{C}$. Climatic conditions across the country are fairly uniform. The northernmost extent of the forest area serves as an important climatic divide. To its north, two distinct seasons occur. Normally, the harmattan season with its dry, hot days and relatively cool nights spans from November through late March or April, and is followed by a wet period that reaches its peak in late August or September. The mean annual rainfall from north to south ranges from $1,250 \mathrm{~mm}$ to $2,150 \mathrm{~mm}$ respectively. Heavy rainfall occurs from about April through late June. After a relatively short dry period in August, another rainy season begins in September and lasts through end of October or early November, before the longer harmattan season sets in to complete the cycle.

An important location in Ghana where forest fringe communities have suffered considerable setbacks in their livelihoods due to climate change is the Offin catchment. Considerable forest loss has occurred due to timber exploitation, farming and other land use activities. Forest fringe communities in the catchment area are characterised by high poverty levels and rely on rain-fed agriculture with little or no access to modern agricultural technology. Although there are 
anecdotal reports of climate deteriorations in the forest areas of Ghana, little or no work has been carried out on how livelihoods in the forest fringe communities have been impacted on variations. This study was conducted to examine the impact of forest loss and concomitant changing climatic conditions on rural community livelihoods in the Offin basin and to document the various coping strategies that have been adopted by the forest fringe communities for sustenance.

\section{MATERIALS AND METHODS \\ Description of study area}

The River Offin basin is located almost in the central portion of Ghana (Fig.1) and traverses the forest zone. Most communities in the Offin basin are predominantly rural and subsistence farmers who depend on the catchment for their livelihoods. The Offin basin provides 80\% (approx 18 million gallons) of potable water daily to the city of Kumasi and metropolis, water for irrigation and a source of fish for the local communities. The basin provides a water transport for the communities and their farm produce. It also provides water for some rural and cottage and industries. It also provides timber and other forest resources such as fuelwood, snails and medicinal plants and a sanctuary for game animals.

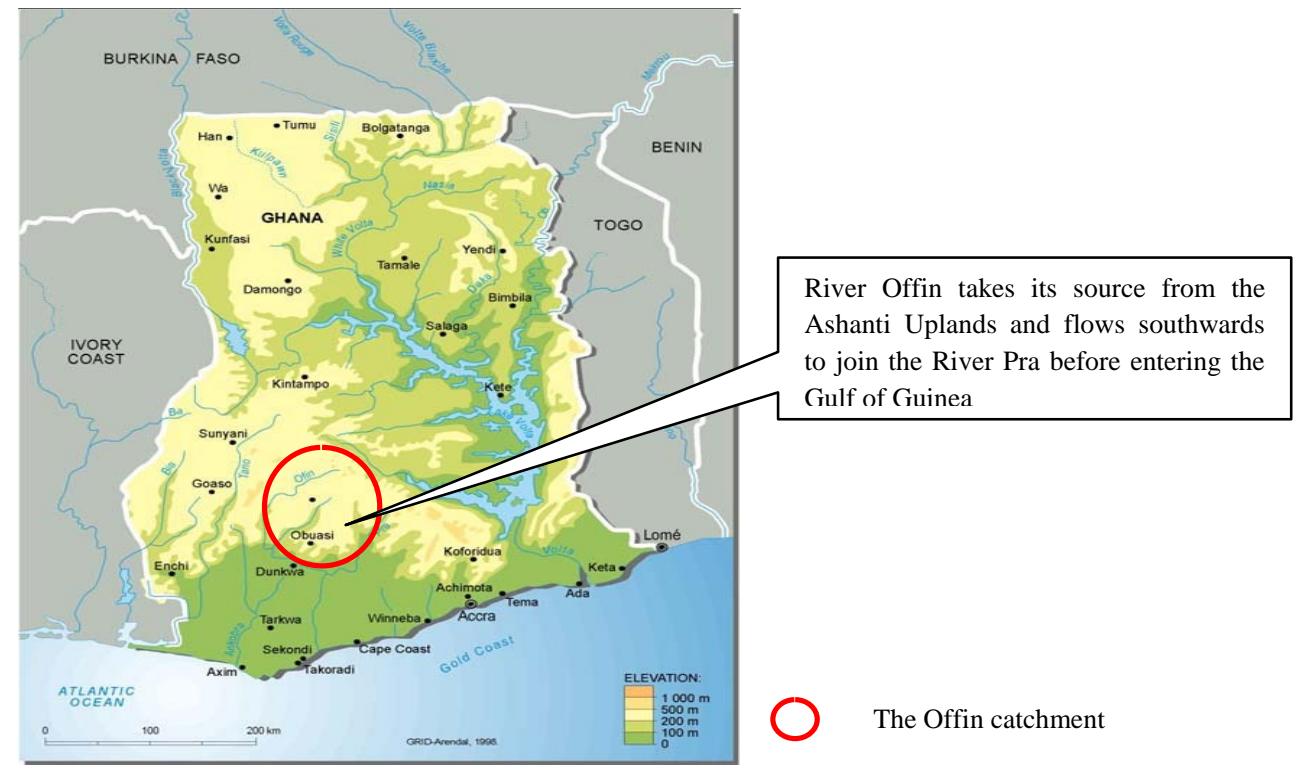

Fig. 1: Map to show the Offin River Basin in Ghana

\section{Data collection and analysis}

Reconnaissance surveys, desk studies, interviews and on-field observations were undertaken in the Offin catchment (Fig. 1) in Ghana to document the status of the forests, riparian vegetation, prevailing climatic conditions and strategies that have been adopted by fringe communities to cope with the changing climatic conditions. Extensive literature surveys were undertaken to gather information on the extent of deforestation over several decades, changes in forest cover, forest types and forest designations.

A total of 46 years of monthly historical rainfall and temperature data were collected from the Ghana Meteorological Agency databases. Temperature and rainfall data were used because these constitute the climatic variables that are likely to reveal changes in extreme values during the period of study. The * Corresponding author: Amisah, S. annual maximum and minimum temperatures and precipitation over the period of 1961-2006 were analysed to establish historical trends using linear regression equation. The seasonal and inter-annual variability were also assessed. River height measurements of the River Offin downstream and upstream from 1957 to 2006 were collected from the Ghana Hydrological Agency office for analysis. Using the Rate Equation from the rating curve of the river, discharge of River Offin was calculated for recorded river heights from 1957 to 2006. The river discharge from 1957 was analysed to establish trends, maximum and minimum discharges, seasonal and inter-annual variability using linear regression. Gathering information on relationship between climate and livelihoods was done through a multifacted approach which was more qualitative and 
quantitative. The methods involved were participatory and integrate the diverse perspectives of the various stakeholders in a holistic manner

The socioeconomic and livelihood dimensions of the study used interviews, semi-structured questionnaires and focus group discussions to set the climate and livelihoods contexts of the communities. Computer software CRiSTAL 3.0 (Community-based Risk Screening Tool - Adaptation and Livelihoods) was used as a guide. CRiSTAL is a decision support tool developed jointly by IISD, IUCN, SEI-US and Intercooperation. Drawing on the Environmental Impact Assessment (EIA) model and the Sustainable Livelihoods Framework (SLF), CRiSTAL provides a logical, user-friendly process to help users better understand the links between climate-related risks, people's livelihoods, and project activities. Themodule 1 of the software was used to synthesise information on climate and livelihoods to provide current climate hazards and impacts of changes on local livelihoods. Natural, physical, social, financial, and human resources of communities in the Offin river basin were also identified. The extents to which these resources enable the people to conduct their livelihoods and cope with climate hazards were assessed. This formed the baseline for the vulnerability of the communities to potential climate change and variability. Three different frameworks for collecting information from rural communities and resource-poor conditions were reviewed and relevant sections adopted for this study. The methodology used is a result of a review, adoption and adaptation of three different frameworks used in collecting data on livelihoods, especially in developing countries. These are (1) CRISTAL 3.0 (Community-based Risk Screening Tool-Adaptation \& Livelihoods), which help in collecting data/information on anticipated impacts of climate change; current climate-related hazards affecting an area, the impacts of these hazards and coping strategies being used by the victims to deal with these impacts; (2) Sustainable Livelihoods Approach (SLA) developed by the DFID and (3) the AgroEcological Knowledge Toolkit developed by the University of Wales, Bangor, UK in conjunction with the Department of Artificial Intelligence at Edinburgh University, which is primarily concerned with gathering local ecological knowledge (LEK), i.e. what people know about their natural environment, based primarily on their own experiences and observation

\section{RESULTS}

Trends in deforestation, temperature and rainfall patterns and the impacts of climate changes on the communities and strategies or mechanisms used to cope with the changes and hazards are presented in the sections that follow:

\section{Deforestation in the Offin basin}

Ghana's forests are $100 \%$ public-owned. About $5,517,000$ hectares representing about $24.3 \%$ of Ghana is forested (Table 1). Of this, about 353,000 hectares (6.4\%) is classified as primary forest (Table 1) the most diverse form of forest. Between 1990 and 2000, Ghana lost an average of 135,400 hectares of forest per year. This amounts to an average annual deforestation rate of 1.82\%. Between 2000 and 2005, the rate of forest change increased by $4.2 \%$ from $1.89 \%$ per annum. In total, between 1990 and 2005, Ghana lost $25.9 \%$ of its forest cover or around 1,931,000 hectares (Table 3). Measuring the total rate of habitat conversion (defined as change in forest area plus change in woodland area less net plantation expansion). For the period 1990-2005 interval, Ghana lost $27.6 \%$ of its forest and woodland habitat.

Table 1: Ghana Land Cover, 2005

\begin{tabular}{lll}
\hline Land Cover & Area (ha) & Percentage (\%) \\
\hline Total Land & $22,754,000$ & \\
Total Forest & $5,517,000$ & 24.25 \\
Primary Forest Cover & 353,000 & 6.40 \\
\hline Primary Forest (\% total land) & 1.55 \\
\hline Source: FAO; Global Forest Resources Assessment 2005; State of the World's Forests 2005
\end{tabular}

Table 2: Ghana: Breakdown of forest types, 2005

\begin{tabular}{|c|c|c|}
\hline Forest Types & Area (ha) & Percentage (\%) \\
\hline Primary forest & 353,000 & 6.4 \\
\hline Modified natural & $5,004,000$ & 90.7 \\
\hline Semi-natural & - & - \\
\hline Production Plantation & 160,000 & 2.9 \\
\hline
\end{tabular}

Table 3: Changes in Forest Cover in Ghana 1990-2005

* Corresponding author: Amisah, S. 


\begin{tabular}{lllll}
\hline Year & Forest Cover (ha) & Period & Annual change (ha) & Percentage change \\
\hline 1990 & 7448000 & & & \\
2000 & 6094000 & $1990-2000$ & 135,400 & -1.82 \\
2005 & 5517000 & $2000-2005$ & 115,400 & -1.89 \\
\multicolumn{5}{l}{ Change in rate } \\
\multicolumn{5}{l}{ Source: FAO; Global Forest Resources Assessment (2005); State of the World's Forests, 2005 }
\end{tabular}

\section{Rainfall fluctuations}

Analysis of time series of data on rainfall highlights some features that represent the hydro-climatological changes over the basin within the last 4 decades (Figure 2). There was a remarkable reduction in mean annual rainfall of $22.2 \%$ from the 1960 s to 2000 s, i.e., mean annual rainfall of $144.8 \mathrm{~mm}$ in $1961-1970$ and $112.7 \mathrm{~mm}$ in 2006. Fig.2 also shows that rainfall did not decline further after the early 1990s. There have been marginal increases of $1.6 \%$ and $4.7 \%$ from 1981-1990 through $1991-2000$ to 2001-2006 respectively. This notwithstanding, the rainfall pattern in the Offin basin cannot be reported to have a wetter regime, because analysis of historical rainfall in other parts of West Africa shows that statistical tests respond with a relatively longer time lag to strong variations (Ozer et. al., 2003). Scientists, therefore, have to wait a little longer after observations and Ozer et. al. (2003), suggests some further 10 years) before inferring any conclusions about rainfall regimes. This scenario has been reported in several parts of West Africa, notably the Sahel (Nicholson, et al., 1996, 2000). Considerable variability in total annual rainfall in four and a half decades with sharp decreases in mean rainfall ( $\leq 1200 \mathrm{~mm}$ ) between 1985 and 2000 were observed. Total mean annual rainfall of $1367.5 \mathrm{~mm}$ was recorded from 1961 to 2006 . The decades 1981-2000 recorded the least mean annual precipitation of 105.9 $\mathrm{mm}$ in the period under study. The highest mean annual precipitation of $144.8 \mathrm{~mm}$ was recorded in the decade of 1961-1970.

Though, seasonal trends did not change much over the years, a main peak in May to June and a trough in July to August with a secondary peak in September to October was observed (Figure 3). This reflects the two rainy peaks in the region and the depression in August represents the short, dry season or August break.

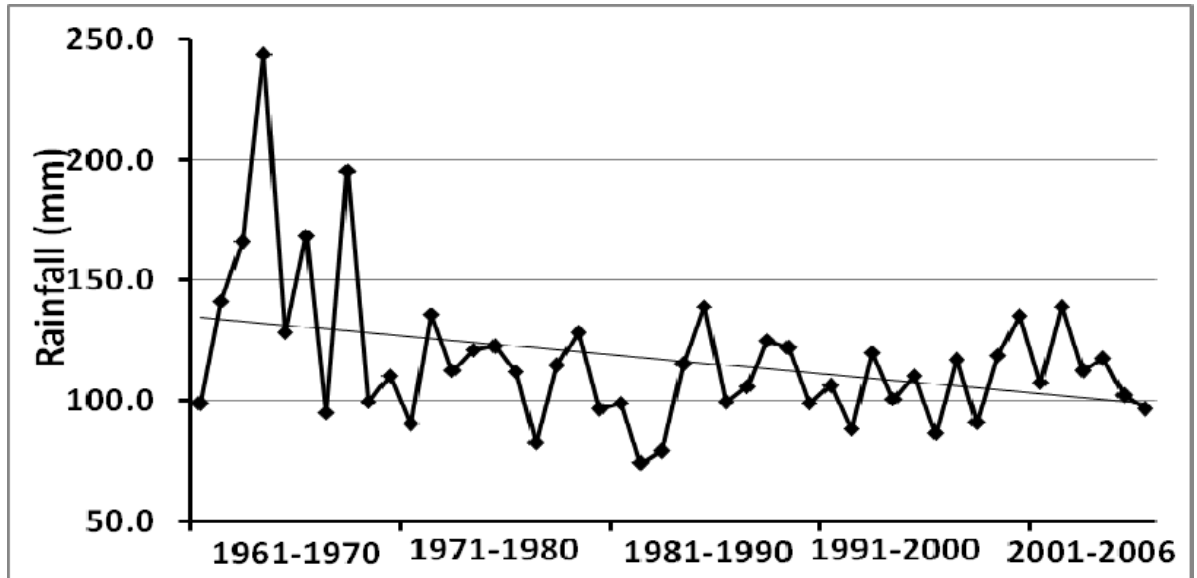

Fig. 2. Trend in mean annual Rainfall in R. Offin basin (1961-2006) 


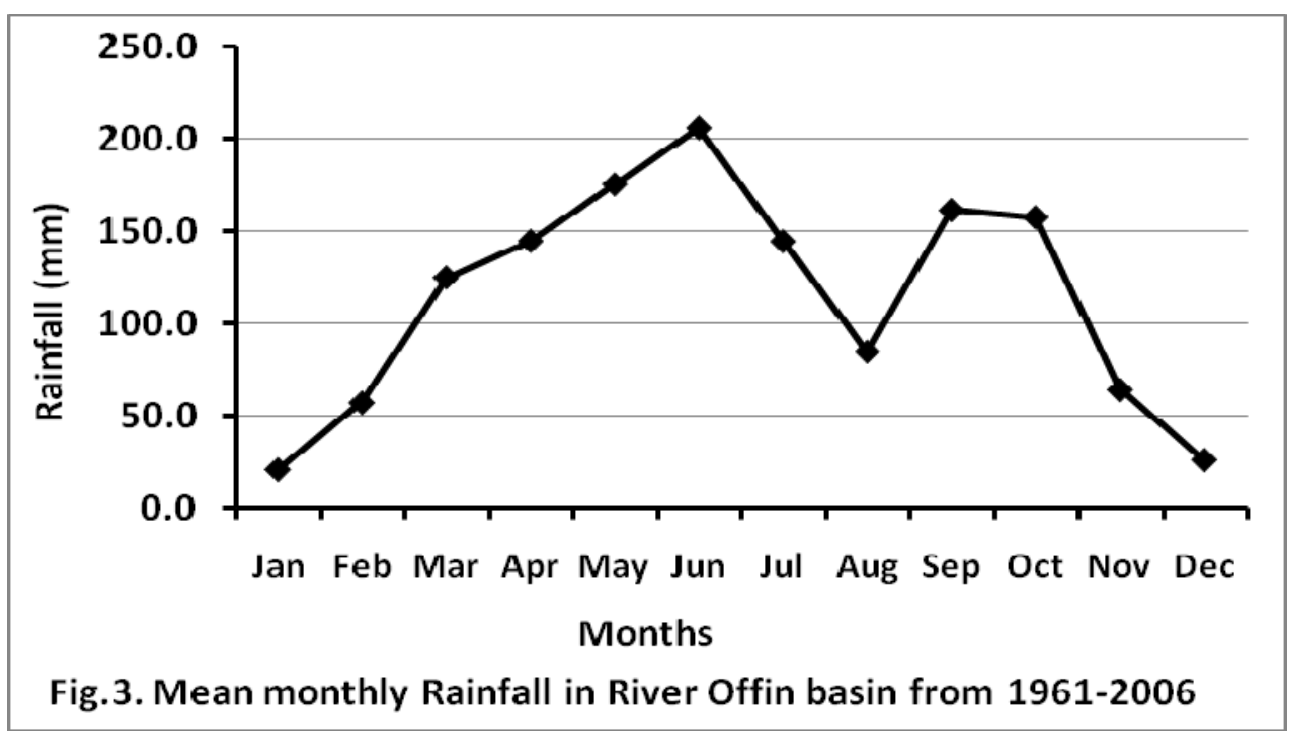

Mean maximum and minimum ambient temperatures

The time series analysis of annual temperature indices indicates that changes in temperature extremes during the period of investigation reflect warming. The general trends of mean maximum and minimum temperature recorded over the period 1961 to 2006 are presented in Fig.4 and Fig.5 respectively. Fig.4 shows a gradual rise in average maximum temperatures over the stated period from $30.2{ }^{\circ} \mathrm{C}$ in 1961 to $31.5{ }^{\circ} \mathrm{C}$ in 2006 , indicating a $1.3^{\circ} \mathrm{C}$ or $4.3 \%$ rise in temperature. The mean minimum air temperature followed a similar trend, starting with an annual mean of $21.1^{\circ} \mathrm{C}$ in 1961 , to $22.1{ }^{\circ} \mathrm{C}$ in 2006 . This is a $1.0{ }^{\circ} \mathrm{C}(4.7 \%)$ rise over the entire period (Fig.5). Over the four and a half decades, there has been a gradual but consistent rise in temperatures, with little variability. From a mean maximum temperature of $30.2{ }^{\circ} \mathrm{C}$ in the first decade of 1961 1970, it rose to $31.4{ }^{\circ} \mathrm{C}$ in 2001 - 2006. 1998 and 1964 are the warmest and coldest years, respectively, in the last 46 years.

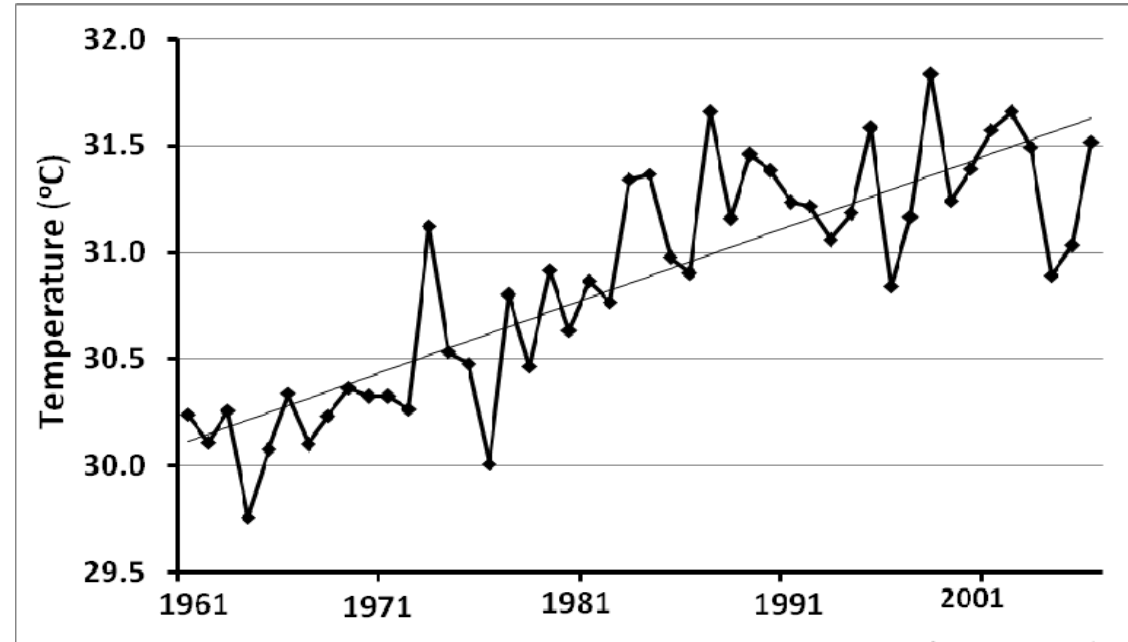

Fig.4. Trend in mean maximum air Temp. in River Offin basin (1961-2006)

\footnotetext{
* Corresponding author: Amisah, S.
} 


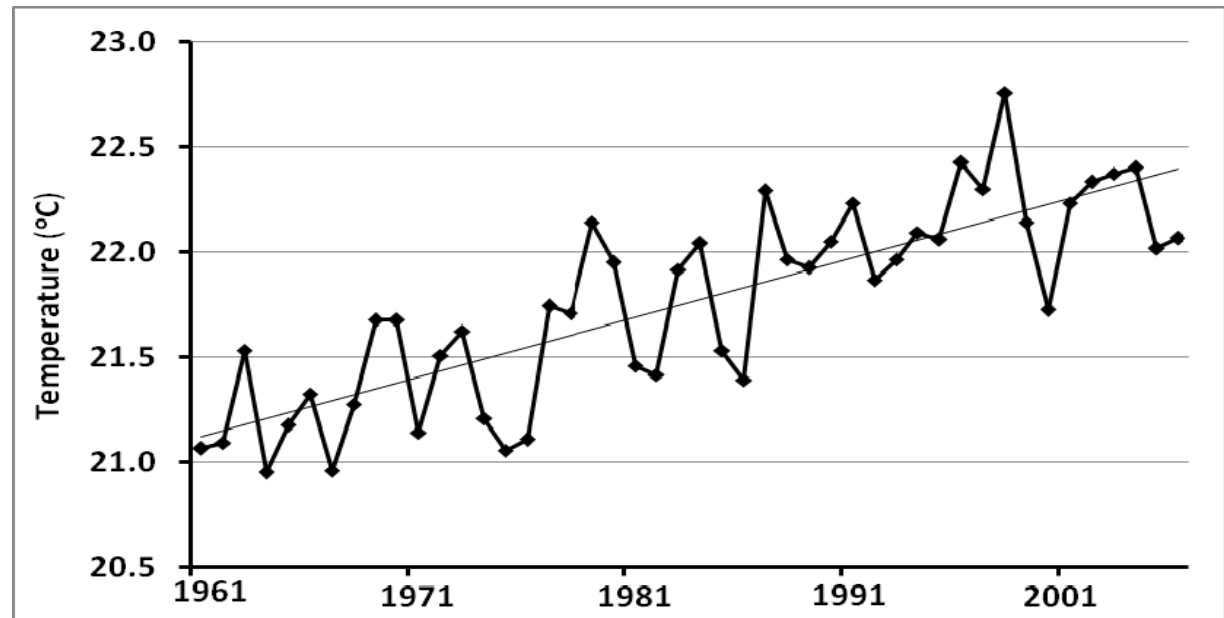

Fig.5. Trend in mean annual minimum temperature in R. Offin basin (1961-2006)

\section{Discharge of River Offin}

Between 1957 and 2006, discharge of River Offin varied considerably (Fig. 6), with the high discharge $8.177 \mathrm{~m}^{3} / \mathrm{s}$ recorded in 1963 and dropping to a low discharge of $0.139 \mathrm{~m}^{3} / \mathrm{s}$ in 1976 . From $6.941 \mathrm{~m}^{3} / \mathrm{s}$ of discharge in 1957, the discharge of the river fluctuated considerably and dropped in 2006 to $3.797 \mathrm{~m}^{3} / \mathrm{s}$. This represented a reduction of $3.144 \mathrm{~m}^{3} / \mathrm{s}$ or $45.3 \%$ in mean annual discharge. Mean monthly discharge followed a similar bimodal pattern as the mean monthly rainfall, with two peaks in June and October. River discharge declined with rainfall (Figs. 6 and 7) with bimodal peaks occurring in October and June, (Fig. 7).

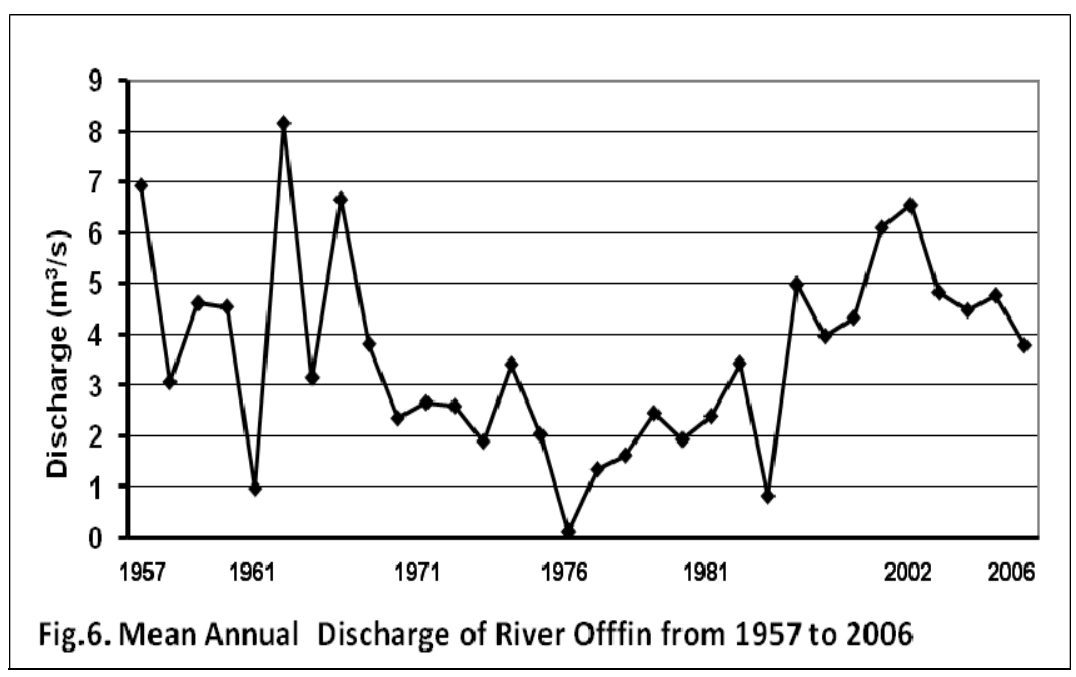

* Corresponding author: Amisah, S. 


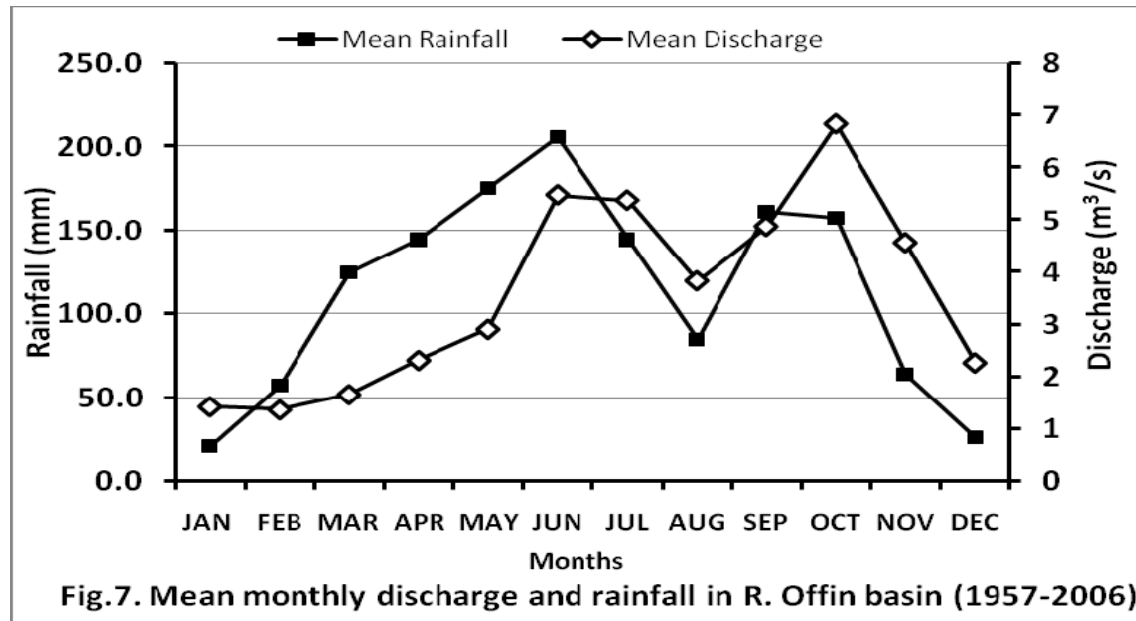

\section{Climate-related hazards and livelihoods}

The participatory rural appraisals and stakeholder interviews identified 3 main climate-related hazards affecting the communities. These were prolonged inadequate rainfalls, drought and extreme heat. Important livelihood resources considered very critical for sustenance and the survival of the communities were identified as (a). Natural Resources - land and forest resources, rivers;

(b). Human resources - Indigenous knowledge, agricultural skills, water management skills and or training; (c) Financial Resources - remittances and savings; (d) Physical resources - wells, bridges, roads; and (e) Social Resources - local Community based organizations, local governance Institutions.

The River Offin and its tributaries provide water for domestic purposes, irrigation and fishing. The forest provides game and other forest products for the community, with some communities deriving almost their entire income from non-timber forest products such as snails, mushrooms and pestles. Prolonged, inadequate rainfalls were identified as major climatic hazards which affected flow of water in the catchment and contributed to crop failure. Respondents in some communities reported that the River Offin became ephemeral and dried up at several stretches during the dry season of 2006 resulting in water scarcity at those times. Other reported hazards were incidences of deteriorating water quality, bilharziasis, shingles, malaria and skin debilitations.

Existing traditional coping strategies by the communities include rainwater harvesting, communal protection and restoration of water courses, and enforcement of community taboos and laws. Others included waiting for rains to set in before planting crops to prevent crop failure and leaving tree cover during arable crop or cash crop farming. The communities further recognised that access to money was important in the face of climate changes but had few or no options to address that.

\section{DISCUSSION}

Deforestation and temperature fluctuations

Deforestation in the tropics accounts for nearly 20 per cent of carbon emissions due to human activities (CSIRO Australia, 2007; FAO, 2007) and continues to play a key role in increasing greenhouse gas concentrations, resulting in global warming and climate change. The deforestation data available aptly reflects the current scenario in the forest fringe communities of the Offin basin, which experiences a comparatively higher deforestation pattern than in similar areas in the country. Over the years, considerable forest lands in the basin have been cleared for cocoa cultivation and timber exploitation. Since Ghana became politically independent in 1957, the timber industry has been vibrant and intensified to enhance economic sufficiency. Successive governments Ghana provided generous incentives to attract investment in various sectors, including mining concessions within some of Ghana's forest reserves (UNEP, 2008). This had serious implications for the biotic and social integrity of the country's forests. Forests serve as carbon sinks and contribute to ameliorating temperatures and providing a congenial climate. There is a strong relationship between deforestation, temperature and climate change. Forest ecosystems provide more carbon sinks than the entire atmosphere (Greenfacts, 2007). Removal of forests, therefore, cause a change in climate by affecting the amount of carbon dioxide in the atmosphere due to the release of carbon stored in vegetation into the atmosphere and via carbon dioxide coming from the combustion of biomass (Mastrandrea and Schneider, 2005). From 1990 through 2000 to $2004 \mathrm{CO}_{2}$ emissions in Ghana have steadily increased from 0.2419 to 0.375 and to 0.326 
metric tonnes per capita, respectively (UNEP, 2008). This is very much expected in locations like the Offin basin where deforestation rates are high and "slash and burn” agriculture is widely practised. Conversion of forested areas into other uses, e.g. mining, has been identified as a contributing factor to climate change, and accounts for $33 \%$ of the increase in atmospheric $\mathrm{CO}_{2}$ since 1850 (de Sherbinin, 2002). Consequent increases in ambient temperatures in the basin increased by $1.0-1.3{ }^{\circ} \mathrm{C}$ between 1961 and 2006 in response to the high rate of deforestation (Figs. 4 and 5)

\section{Deforestation, precipitation and discharge in the Offin Basin}

The effects of deforestation on precipitation patterns and distributions appear well accepted globally. Deforestation changes precipitation patterns and distributions by affecting the amount of both sensible heat and that is released into the atmosphere when water vapour condenses ((NASA/Goddard Space Flight Center, 2005). Analysis of multiple years of data using the NASA Goddard Institute for Space Studies General Circulation Computer Model (GCM) and Global Precipitation Climatology Project (GPCP) to produce several climate simulations showed that deforestation in different areas of the globe affects rainfall patterns over a considerable region. A discernible dependence of rainfall on vegetation has been simulated and/or discussed in several papers ( Dickinson, 1980; Anthes 1984; Avissar, 1992 Sud and Fenessey, 182, 1984).

Removal of vegetation in any typical region can lead to reduction in evapotranspiration and/or land surface roughness and result in a decrease in rainfall (Sud and Smith, 198; Sud and Molod, 1988; Walker et. al., 1995). Although majority of the models simulate substantial decreases in rainfall in response to deforestation, it must be mentioned that a few models simulate no change or even an increase in rainfall but such Eltahir and Bras (1993) show that such differences are caused by the competing effects of moisture convergence produced by the troposphere and moisture deficit caused by reduced evapotranspiration in deforestation. The current scenario in rainfall and temperature patterns in the Offin basin would be expected, in the light of deforestation rates and the general rainfall patterns throughout Ghana, where dry conditions have prevailed in most parts since the late 1960s. There are strong evidences to show that forest loss have strong links with reductions in precipitation. Between 1968 and 1997, rainfall in West Africa, has on average, ranged from 15\%-40\% lower than during the period 1931-60 (Nicholson, 1999). Mean annual rainfall in the Offin basin also decreased by $22.2 \%$ from 1960 to 2006, which is in the range of earlier

\footnotetext{
* Corresponding author: Amisah, S.
}

studies (Niasse, 2005; Nicholson, 1999). Research findings already suggest that deforestation along the southern coast of West Africa (.e.g. Nigeria, Ghana and Ivory Coast) may result in complete collapse of the monsoon climate circulation and significant reduction of regional rainfall (Zheng and Eltahir, 1997)

Another important feature of the rainfall in the basin is the seasonal variability or its erratic pattern. The Offin basin continues to experience changes in the rainfall pattern. Rainfall can no longer be predicted by farmers with accuracy as was previously the case. Farmers have always predicted the inception of rains and planted their crops to meet the season but the rainfall pattern now remains unpredictable. This has negatively affected both arable and cash crop production since the farmers depend on rain-fed agriculture.

In response to climate change, it is predicted that some areas will receive more river runoff while other parts will see a decrease in resource availability. Runoffs or discharges in all river basins in Ghana are sensitive to changes in precipitation and temperature, and thus to climate change. A $10 \%$ change in precipitation or a $1^{\circ} \mathrm{C}$ rise in temperature can cause a reduction in runoff of not less 10\% (EPA, 2000). Water budgets of forest ecosystems are heavily dependent on climate and forest structure, hence increasing air temperature, coupled with reduced rainfall could increase the evaporative demands of forest ecosystem. Deforestation frequently leads to water loss; this combined with high temperatures and reduced rainfall affected flow or discharge of the River Offin to decline from from $6.941 \mathrm{~m}^{3} / \mathrm{s}$ in 1957 to $3.797 \mathrm{~m}^{3} / \mathrm{s}$ in 2006 , indicating a $3.144 \mathrm{~m}^{3} / \mathrm{s}$ (45.3\%) reduction. At this rate, the River Offin could well become an ephemeral stream. This scenario could have devastating consequences for the dependent communities whose livelihoods are directly dependent on the basin.

\section{Coping strategies in response to climatic changes in the Offin basin}

Drought results in water shortages, reduced water quality, bush fires and food insecurity in the forest fringe communities of the Offin basin. As the climate deteriorates, there is reason to believe that drought hazards will increase (Downing and Ludeke, 2002). In the late 1970 s and 1980 s, severe droughts and bush fires destroyed forests and farms in the area, resulting in massive crop failure and hunger, livestock losses, malnutrition and increased health risks. During the years of prolonged rainfall deficits in the region, water shortages lead to crop damage and or loss and consequent loss of income to the dependent in the communities in the basin. Water 
related diseases such as bilharziasis, diarrhoea and malaria are common during these times (NsiahGyabaah, 2001). Extreme heat predisposes communities to ailments such as shingles and heat rashes and exposure to insect bites from mosquitoes that cause malaria fever. Treatment of these ailments places further stress on the financial resources of the communities. To cope with water shortages, the Offin basin communities resort to water rationing. For example, water used for domestic activities is also used for backyard gardening and rain water is harvested for domestic use. Traditional and local authorities have realised the impacts of felling of trees along river banks and are embarking awareness campaigns to stop the practice. They communities are now aware that, e.g. riparian vegetation provide shade, lower water temperatures and bankside habitat for wildlife and may also reduce erosion of river banks.

Given the potentially dramatic effects on local climate, natural resources, infrastructure and economic activities, the basin may be particularly vulnerable to risk or effects from climate change (Eriksen, 2001). In the catchment area, bushfires are common during droughts and occur annually in the dry season from November to March. Large tracts of farms and forests are destroyed during such fires. Records indicate that only $20 \%$ of the forest zone in Ghana is currently covered by forest which has not been burnt regularly (Hawthorne, 1994). Education on bush fire prevention and control remains an ongoing process in the study area.

Financial resources constitute the main livelihoods resource facilitating adaptation to the effects of climate change in the study area. Traditionally, the main source of financial resources is from farming and exploitation of forest products, which has decreased considerably over the years. Households with good financial resources are better able to cope with adverse effects of climatic change. Households with strong financial resources are able to replant their farms, purchase big water storage containers to hold water for later use and also access conventional medical treatment.

The communities have used their indigenous knowledge on water management and conservation, which has been passed on from one generation to another, to cope with water shortages, droughts, crop damage and losses. Recently, local government institutions and traditional authorities have provided wells fitted with hand pumps to improve water and sanitation in the area. Bye-laws and tree planting programmes have also been initiated to protect the water resources in the communities. Others include, good road infrastructural network to ease the transportation to urban areas, which has helped rural- urban migrants to find casual work to earn extra income or for farmers to access large market centres. Communities living in the Offin river basin depend on renewable natural resources for survival but their activities have also contributed to considerable loss of forest cover and impacted on the climate. Climatic changes manifested as rainfall shortages, temperature surges and droughts significantly affect livelihood resources of communities making them vulnerable to hunger and poverty.

Climatic changes in the Offin basin have certainly influenced livelihood trends and communities have adopted various survival strategies to cope with the changes. There is a need to modify and integrate some of the traditional adaptation practices that farmers themselves have adopted to respond to future trends as the climate continues to undergo change. For example, it is suggested that degraded forest areas be rehabilitated or re-vegetated and mass tree planting activities be undertaken by the riparian communities.

Traditional authorities, government, policy makers and all relevant stakeholders need to collaborate to find alternative, sustainable livelihoods for the forest fringe communities in the Offin basin, who currently depend mainly on the forests and forest products. This will enhance efforts to address climate-related hazards. The climatic impact on the forest fringe communities of the Offin basin appears not to be an isolated one. Anecdotal information suggests that other forest fringe communities in Ghana are facing similar climate-related problems. The livelihoods of the fringe communities are very much linked to their cultural practices. It is important, therefore, that the alternative sustainable livelihoods in one fringe community are not simply extrapolated to other areas but each viewed in its own merit. Reducing deforestation and encouraging re-afforestation and restoration of degraded riparian vegetation to improve climatic conditions will, invariably, enhance livelihoods in the forest fringe communities in the Offin catchment.

Acknowledgements: We acknowledge the support of the Department of Fisheries and Watershed Management of the Kwame Nkrumah University of Science \& Technology, CRSP-USAID, and the Meteorological Services of Ghana for their cooperation.

\section{REFERENCES}

Anthes, R. A., 1984: Enhancement of convective precipitation by mesoscale variations in vegetative covering in semi-arid regions. $J$. Climate Appl. Meteor., 23, 541-554. 
Avissar, R., 1992: Conceptual aspects of a statisticaldynamic approach to represent landscape subgrid-scale heterogeneities in atmospheric models. J. Geophys. Res., 97 (D3), 2729-2742.

CRISTAL (Community-based Risk Screening Tool Adaptation \& Livelihoods) Version 3.0, (2006). A decision support tool for assessing and enhancing project impacts on local adaptive capacity to climate variability and climate change. IISD, IUCN, SEI-B and Intercooperation.

CSIRO Australia (2007). Confirmed: Deforestation Plays Critical Climate Change Role. ScienceDaily, May 11. http://www.sciencedaily.com/releases/2007/05/0 70511100918.htm Retrieved February 27, 2008

Dickinson, R. E., 1980: Effect of tropical deforestation on climate. Blowing in the wind: Deforestation and long range implication, studies in the third world societies. Department Anthropology, College of William and Mary Publication No. 14, 411-441.

Downing, T. and Lüdeke, M., (2002). 'International Desertification: Social Geographies of Vulnerability and Adaptation', Dahlem Workshop Report on Global Desertification: Do Humans Cause Deserts? ISBN 3-934504-10-8. Website: Dahlem Konferenzen der FREIEN UNIVERSITÄT

Eltahir, E. A. B., (1992). Drought frequency analysis of annual rainfall series in central and western Sudan. Hydrol. Sci. J., 37, 185- 199.

Environmental Protection Agency, Ghana, (2000). Climate Change Vulnerability and Adaptation Assessment on Water Resources of Ghana. Final Report

Eltahir, E. A. B., and R. L. Bras, 1993: On the response of tropical atmosphere to large-scale deforestation. Quart. J. Roy. Meteor. Soc., 119, 779-793.

Eriksen, S., (2001). 'Linkages between climate change and desertification in East Africa', Arid Lands Newsletter No. 49, May/June. ISSN: 1092-5481. http://ag.arizona.edu/ OALS/ALN/ aln49/eriksen-part1.html

FAO, (2007). State of the World's Forest 2007. Food and Agricultural Organization. Rome, Italy. [www.fao.org]

FAO, (2006). Global Forest Resources Assessment 2005. Progress towards sustainable forest

* Corresponding author: Amisah, S. management. Food and Agriculture Organisation of the United Nations. Rome. 320 pp.

FAO, (2005). State of the World's Forests 2005. Food and Agriculture Organisation of the United Nations. Rome. 153pp

Farmer, G., and T. M. L. Wigley, (1985). Climate trends for tropical Africa. Research Rep. for the Overseas Development Administration, 136 pp. [Available from Climate Research Unit, School of Environmental Sciences, University of East Anglia, Norwich NR4 7TJ, United Kingdom.]

Greenfacts (2007). Scientific Facts on Forests: Level 1. Greenfacts Digest. Available at: http://www.greenfacts.org/en/forests/

Hawthorne W. D., (1994). Fire Damage and Forest Regeneration in Ghana. ODA Forest Series 4. Natural Resources Institute, Chatham, 53 pp.

Horton, E. B., and D. E. Parker, (1997). Global and regional climate in 1996. Weather, 52, 174-182.

Hulme, M., (1994). Century-scale series of regional rainfall anomalies in Africa. Trends (93): A Compendium of Data on Global Change, T. A. Boden et al., Eds., Carbon-Dioxide Information Analysis Center, Oak Ridge National Laboratory, 964-973.

Mastrandrea, M. D., and Schneider, S. H., (2005). "Global warming." World Book Online Reference Center. World Book, Inc. http://www.worldbookonline.com/wb/Article?id $=\operatorname{ar} 226310$.

NASA/Goddard Space Flight Center (2005). Tropical deforestation affects rainfall in the U.S. And Around The Globe. ScienceDaily, September18.

http://www.sciencedaily.com/releases/2005/09/05091 8132252.htm. Retrieved February 27, 2008.

Niasse, M., (2000). Climate-Induced Water Conflict Risks in West Africa: Recognizing and Coping with Increasing Climate Impacts on Shared Watercourses. Paper Presented at Human Security and Climate Change workshop, 21-23 June, Asker, Norway.

Nicholson, S. E., (1994). Century-scale series of standardized annual departures of African rainfall. Trends (93): A Compendium of Data on Global Change, T. A. Boden et al., Eds., Carbon-Dioxide Information Analysis Center, Oak Ridge National Laboratory, 952-962. 
Nicholson, S. E.M. B. Ba, and J. Y. Kim, (1996). Rainfall in the Sahel during 1994. J. Climate, 9, 1673-1676.

Nicholson, S.E., Some, B. and Kone, B., (1999). 'An Analysis of Recent Rainfall Conditions in West Africa, Including the Rainy Seasons of the 1997 El Niño and the 1998 La Niña Years', Journal of Climate, Vol. 13, pp 2628-2640.

Nicholson, S. E., Somé, B., Kone, B. (2000) An analysis of recent rainfall conditions in West Africa, including the rainy seasons of the 1997 El Niño and the 1998 La Niña years. J. Climate 13(14), 2628-2640.

Nsiah-Gyabaah, K., (2001). The Looming National Dilemma of Water Crisis in Peri-Urban Areas in Ghana. Paper Presented at Second Workshop on Peri-Urban Natural Resources Management Project at the Watershed Level (DFID Funded Project R 7330).

Ozer, P., Epricum, M., Demaree, G., and Vandiepenbeeck, M., (2003). The Sahelian drought may have ended during the 1990s. Discussion of "Analysis of a Sahelian annual rainfall index from 1896 to 2000; the drought continues" Hydrological Sciences 48(3) June 2003, pp. 489-496.

Sud, Y. C., and M. J. Fennessy, (1982). A study of the influence of surface-albedo on July circulation in semi-arid regions using the GLAS GCM. J. Climatol., 2, 105-125.
Sud, Y.C, and W. E. Smith, (1985). Influence of local land-surface processes on the Indian monsoon: A numerical study. J. Climate Appl. Meteor., 24, 1015-1036.

Sud, Y. C., D. M. Mocko, and G. K. Walker, (2001). Influence of Land Surface Fluxes on Precipitation: Inferences from Simulations Forced with Four ARM-CART SCM Datasets. Journal of Climate, Vol 14, 3666-3691.

Sud, Y. C., and A. Molod, (1988): A GCM simulation study of the influence of Saharan evapotranspiration and surface-albedo anomalies on July circulation and rainfall. Mon. Wea. Rev., 116, 2388-2400.

United Nations Environment Programme - World Conservation Monitoring Centre (UNEPWCMC). (2004). World Database on Protected Areas. http://www.unep-wcmc.org/wdpa/index. htm

UNEP (2008), “Africa: Atlas of Our Changing Environment." Division of Early Warning and Assessment (DEWA), United Nations Environment Programme (UNEP). Nairobi, Kenya. pp 182-187.

Walker, G. K., Y. C. Sud, and R. Atlas, 1995: Impact of the ongoing Amazonian deforestation on local precipitation: A GCM simulation study. Bull. Amer. Meteor. Soc., 76, 346-361

Zheng, X., and Eltahir, E. A., (1997). The Response to Deforestation and Desertification in a Model of West African Monsoons. Geophysical Research Letters, Vol. 24, no. 2. pp. 155-158. 